\title{
Review of Methane Seepages in the Okinawa Trough: Progress and Outlook
}

\author{
Ang Li $\mathbb{D}^{1,2}$ Qing Li ${ }^{1},{ }^{1,2}$ Cuiling Xu, ${ }^{1,2}$ Feng Cai, ${ }^{1,2}$ and Hongbin Wang ${ }^{1,2}$ \\ ${ }^{1}$ Key Laboratory of Gas Hydrate, Ministry of Natural Resources, Qingdao Institute of Marine Geology, Qingdao 266071, China \\ ${ }^{2}$ Laboratory for Marine Mineral Resources, Qingdao Pilot National Laboratory for Marine Science and Technology, \\ Qingdao 266071, China
}

Correspondence should be addressed to Ang Li; ang.li_cn@outlook.com and Qing Li; qing.li@live.cn

Received 3 March 2021; Revised 29 August 2021; Accepted 22 October 2021; Published 12 November 2021

Academic Editor: Wei Zhang

Copyright (c) 2021 Ang Li et al. This is an open access article distributed under the Creative Commons Attribution License, which permits unrestricted use, distribution, and reproduction in any medium, provided the original work is properly cited.

It has been two decades since the cold seeps were firstly found in the Okinawa Trough (OT). The scientific cruises and the geological surveys since then have unveiled the currently active submarine methane seeps and significantly improved the understanding of methane seeps in the back-arc basin of the OT. In this paper, we review the up-to-date progress of the research of methane seepages then put forward the promising, yet challenging, outlook by listing the unsolved questions of the cold seeps in the OT. Multiple approaches and techniques, including seismic and echo-sounder recording, dredging, gravitypiston and ROV coring, seafloor drilling, and isotopic and microarray-based genomic analysis, have been used to reveal the geological processes responsible for the seeping activities and the biogeochemical processes related to them. The geophysical signature associated with gas seeps mainly includes the acoustic turbidity in the subsurface, the anomaly of the backscattering intensity at the seabed, and the gas plumes observed in the water column. Pore water and methane-derived authigenic carbonate archive the intensification of methane seepage and the paleoenvironment changes at different time scales. The methane feeding of the seeps in the OT was generated mostly via the microbially mediated process and has an origin mixed by thermogenic hydrocarbon gas in the middle OT. Sulfate-driven and Fe-driven anaerobic oxidations of methane are suggested to be the key biogeochemical processes, which would shape the material cycling in the seeping environment. The future research on the cold seeps in the OT is worth looking forward to due to its geographic and potential geologic links with the nearby hydrothermal activities. Multidisciplinary studies are expected to concentrate on their link with the undiscovered gas hydrates, the amount of methane transferring into the oceans and its impact on the climatic change, and the evolution of the seeping activities accompanied by the biogeochemical processes.

\section{Introduction}

Cold seeps are seafloor expressions of the upward migration of methane-rich gases through the marine sedimentary succession [1-3]. This migration involves the varying gas fluxes with time at the seabed and the alternation between the seeping and the diffusion of gases within an area smaller than a couple of square kilometers at one seeping site [1]. It has attracted increasing scientific attention since it was detected by side-scan sonar offshore Nova Scotia, Canada [4]. Methane escaping from the submarine seeps constitutes an important part of the output of the carbon from the marine sediments into the oceans [5]. This makes the world- wide seeps a window to evaluate the impact of the methane on climatic change and study the diverse methanedependent ecosystem [6]. The predictable consequences of considerable methane seepage from seafloor include the amplification of ocean deoxygenation and acidification and, which is still under debate, the atmospheric greenhouse gas concentrations [7-9].

The cold seeps out of the shelf of the East China Sea in the Okinawa Trough (OT) were firstly found along its western slope of the middle part $\left(\sim 26.2^{\circ} \mathrm{N}\right)$ during the scientific cruise in 2000 [10]. Since then, there has been some scientific cruises and geological surveys over the broad marine region (Figures 1 and 2), which provide geophysical and 


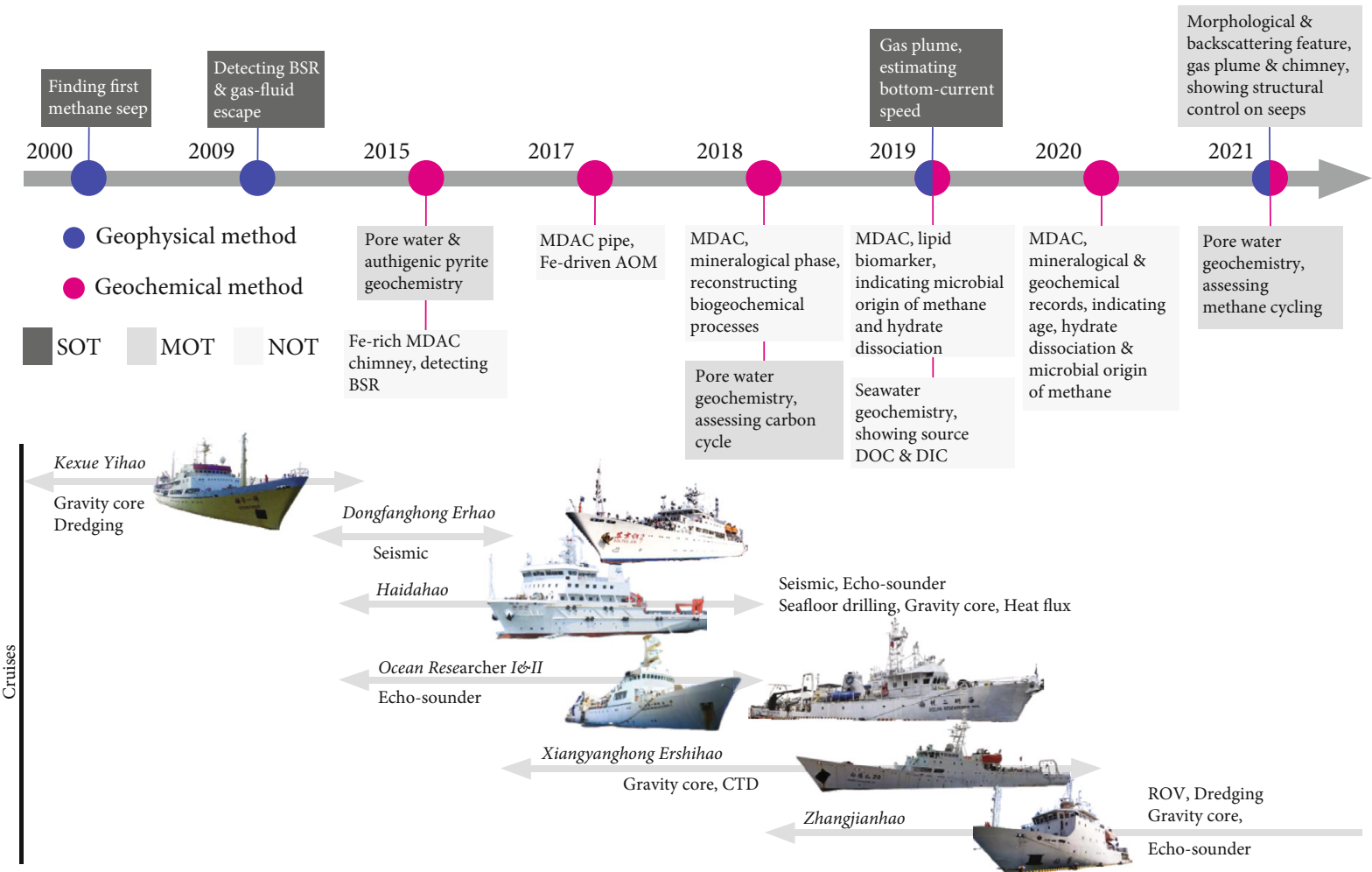

FIgURE 1: Timeline of the key researches and the cruises in the Okinawa Trough. SOT: southern Okinawa Trough; MOT: middle Okinawa Trough; NOT: northern Okinawa Trough in this and the subsequent figures and tables; MDAC: methane-derived authigenic carbonate; AOM: anaerobic oxidation of methane; DOC: dissolved organic carbon; DIC: dissolved inorganic carbon; BSR: bottom simulating reflector.

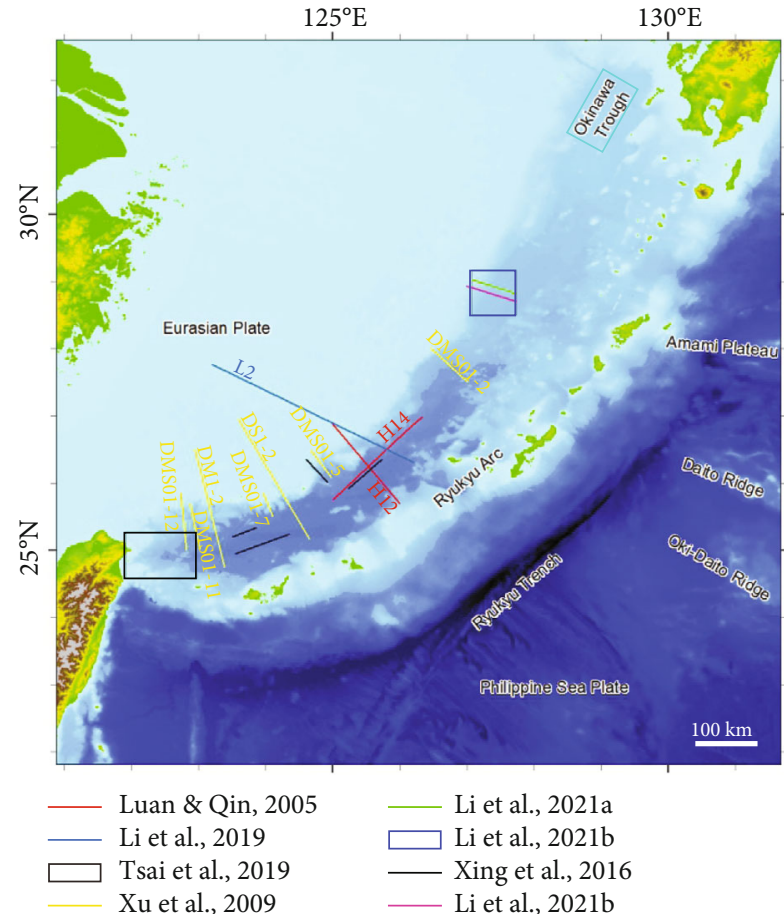

(a)

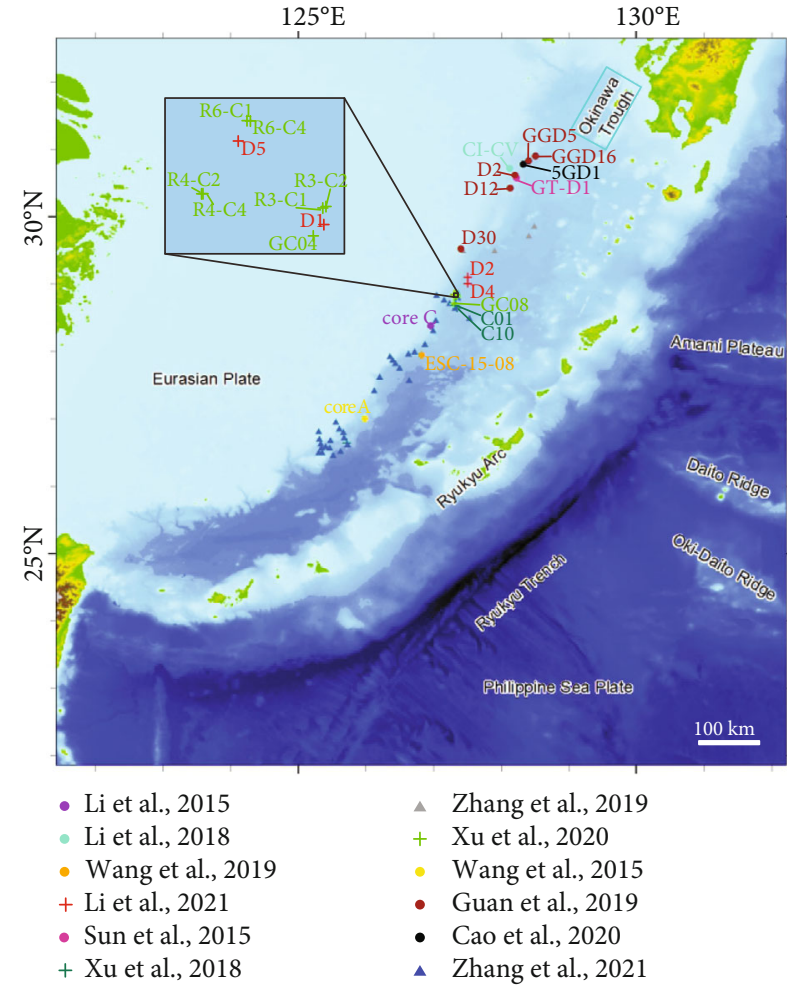

(b)

Figure 2: The locations of the seismic profiles (a) and the coring sites (b) documented in previous studies of methane seepage in the Okinawa Trough. 
TABLe 1: Acoustic observations associated with gas seeps in the Okinawa Trough.

\begin{tabular}{|c|c|c|c|}
\hline Reference & $\mathrm{R} / \mathrm{V}$ & Method & Observations \\
\hline Luan and Qin[10] & Kexue Yihao & $\begin{array}{c}\text { Echo-sounder } \\
\text { HLAC } 15 \text { and } 150 \mathrm{kHz} \\
\text { Single-channel seismic, air gun }\end{array}$ & Gas column, acoustic turbidity, mud diapir in MOT \\
\hline $\mathrm{Xu}$ et al. [11] & Kexue Yihao & 2-D multichannel seismic data & $\begin{array}{c}\text { Mud diapir, migration of free gases along normal faults, } \\
\text { BSR and AWO, high velocity in SOT }\end{array}$ \\
\hline Li et al. [13] & N.D. & 2-D seismic data & $\begin{array}{l}\text { Shelf-margin deltas, submarine channels and canyons, } \\
\text { slope and floor fans, mud volcanoes, gas leakage, BSR }\end{array}$ \\
\hline Tsai et al. [14] & Ocean researcher I\&II & $\begin{array}{l}\text { Single-beam echo-sounder } \\
\text { EK60 } 38 \mathrm{kHz}\end{array}$ & Gas plume, hydrothermal circulation in SOT \\
\hline Li et al. [15] & $\begin{array}{l}\text { Dongfanghong Erhao } \\
\text { Haida Hao }\end{array}$ & $\begin{array}{l}\text { 2-D multichannel seismic data, } \\
\text { sparker } \\
\text { Multibeam echo-sounder } \\
\text { EM122 } 12 \mathrm{kHz}\end{array}$ & $\begin{array}{l}\text { Gas plume, seafloor doming, backscattering features, } \\
\text { seeps in transtensile regime in MOT }\end{array}$ \\
\hline Li et al. [16] & $\begin{array}{l}\text { Dongfanghong Erhao } \\
\text { Haida Hao }\end{array}$ & $\begin{array}{l}\text { 2-D multichannel seismic data, } \\
\text { sparker } \\
\text { Multibeam echo-sounder } \\
\text { EM122 } 12 \mathrm{kHz}\end{array}$ & $\begin{array}{c}\text { Gas plume, seafloor doming, backscattering features, gas } \\
\text { chimney, } \\
\text { spatial relationship between faults and seeps in MOT }\end{array}$ \\
\hline
\end{tabular}

NOT: northern Okinawa Trough; MOT: middle Okinawa Trough; SOT: southern Okinawa Trough; N.D.: not documented.

geochemical data (Tables 1 and 2) for continuous research and significantly contribute to the understanding of the methane seepage in the OT. Multiple ship-based approaches have been used to focus on these seeps of different spatiotemporal dimensions. The acoustic ones mainly consist of seismic and echo-sounder, and together reveal the locations of the seeps and their features from the subsurface and the seabed to the water column [10-16]. The pore water and the authigenic minerals serve as the main geological record of the seeps and have been sampled by grabbing of remotely operated vehicles (ROVs), dredging and gravity-piston coring, and seafloor drilling. Geochemical investigation of these samples reveals the involved biogeochemical processes, the origin of the methane, the interaction between the pore fluids and the seep-impacted sediments, and the evolution of the seeps [17-28]. The seeps studied most in the OT are in its northern section $\left(30.5^{\circ} \mathrm{N}-30.8^{\circ} \mathrm{N}\right)$ and were detected by $R / V$ Kexue Yihao from July to August 2013 [18]. These unnamed seeps become the first group of targets of multidisciplinary research.

The OT is an incipient back-arc basin and formed after the middle Miocene due to the crustal stretching of the Eurasian lithosphere [29]. The geology of the seeps in the OT is less structurally and bathymetrically complex than those in the other oceans (e.g., South China Sea) [30-32]. The most striking feature of the cold seeps in the OT is the impact from the nearby hydrothermal activities that can provide abundant metal oxides to react in the microbially mediated processes of the seeping environment [25]. Additionally, the relatively uncomplicated tectono-structural setting of the OT allows us to probe into how the cold seeps are distributed in the back-arc basin.

The abovementioned knowledge is of importance in reconstructing the seepage activity and its nearby carbon cycling. This paper will review the geophysical features and the geochemical constraints of the seeps in the northern, middle, and southern Okinawa Trough (NOT, MOT, SOT) then put forward the unsolved, yet important, scientific questions. This is a preliminary attempt to look for the research focus in the next step.

\section{Geophysical Signature}

2.1. Seismic Features. Identifying the migration pathway of focused fluid flow can provide an intuitive understanding of methane seepage in its preliminary study and thus is important for subsequent research. Detecting the pathway in the OT relies on the seismic reflection data, as did in other oceans around the globe (c.f. [33]). In specific, these data can reveal the migration of gas-rich pore fluids based on the geophysical signature of reflection disturbance because free gases can cause a decrease in $\mathrm{P}$-wave velocity, severe ray bending, signal scattering, and high transmission loss [34, 35]. The detected pathways favored by gas bypassing the overburden sediments include the high-angle faults and fractures; both of which largely increase the vertical permeability and hence provide the pressure communication for free gases with the surface [36]. Such kinds of faults have been documented to form by the back-arc extension [15] or occur within the underlying diapirs [11-13] (Figures 3(a) and 3(b)). Their spatial relationship with the geophysical signature of the free gases (e.g., acoustic wiping-out and curtain, Luan and Qin, 2005, Figure 3(c)) supports their common role in acting as the migration conduits. The permeable clusters of the subvertical fractures together with the transported free gases were often imaged as the gas chimneys on the seismic cross sections in the MOT [16]. The interpretation of the gas chimneys here sticks to its primitive definition, and their geometries are columnar, rather than irregular. Their bottoms are indiscernible due to the relatively low penetration and high dominant frequency of the seismic data. 3-D seismic data are required to further reveal the rooting zone to better 
TABLE 2: Results of geochemical analysis associated with gas seeps in the Okinawa Trough.

\begin{tabular}{|c|c|c|c|c|c|c|c|}
\hline Reference & Sample no. & Longitude & Latitude & Method & $\mathrm{R} / \mathrm{V}$ & $\begin{array}{c}\text { Water } \\
\text { depth }(m)\end{array}$ & Results \\
\hline \multirow{2}{*}{ Li et al. [17] } & & $126^{\circ} 20^{\prime} 20.4^{\prime \prime} \mathrm{E}$ & $27^{\circ} 40^{\prime} 15.0^{\prime \prime} \mathrm{N}$ & \multirow{2}{*}{$\begin{array}{l}\text { Gravity } \\
\text { core }\end{array}$} & \multirow{2}{*}{ Kexue Yihao } & 1105 & \multirow{2}{*}{$\begin{array}{c}\text { Pore water: concentrations } \\
\text { of } \mathrm{CH}_{4}, \mathrm{SO}_{4}{ }^{2-}, \mathrm{HS}^{-}, \mathrm{TA} \\
\mathrm{NH}^{4+}, \mathrm{PO}_{4}{ }^{3-}\end{array}$} \\
\hline & Core C & $126^{\circ} 58^{\prime} 7.2^{\prime \prime} \mathrm{E}$ & $28^{\circ} 22^{\prime} 10.8^{\prime \prime} \mathrm{N}$ & & & 520 & \\
\hline Sun et al. [18] & GT-D1 & $128^{\circ} 08^{\prime} 00^{\prime \prime} \mathrm{E}$ & $30^{\circ} 43^{\prime} 00^{\prime \prime} \mathrm{N}$ & $\begin{array}{l}\text { Geological } \\
\text { dredging }\end{array}$ & Kexue Yihao & 622 & $\begin{array}{c}\text { MDAC: mineralogical and } \\
\text { geochemical composition, } \\
\delta^{13} \mathrm{C}, \delta^{18} \mathrm{O}, \delta^{56} \mathrm{Fe} \\
\delta^{57 / 54} \mathrm{Fe}, \mathrm{AMS}{ }^{14} \mathrm{C} \text { dating }\end{array}$ \\
\hline Wang et al. [19] & $\begin{array}{l}\text { Core A } \\
\text { Site } 79\end{array}$ & $126^{\circ} 20^{\prime} 20.4^{\prime \prime} \mathrm{E}$ & $27^{\circ} 40^{\prime} 15^{\prime \prime} \mathrm{N}$ & $\begin{array}{l}\text { Gravity } \\
\text { core }\end{array}$ & Kexue Yihao & 1105 & $\begin{array}{c}\text { TOC, pyrites: } \delta^{34} \mathrm{~S} \\
\text { Pore water: concentrations } \\
\text { of } \mathrm{CH}_{4}, \mathrm{SO}_{4}{ }^{2-}\end{array}$ \\
\hline Peng et al. [20] & GT-D1 & N.D. & N.D. & $\begin{array}{l}\text { Geological } \\
\text { dredging }\end{array}$ & Kexue Yihao & N.D. & $\begin{array}{l}\text { MDAC: mineralogical and } \\
\text { geochemical composition, } \\
\text { pyrites: } \delta^{34} \mathrm{~S}, \delta^{56} \mathrm{Fe}\end{array}$ \\
\hline Li et al. [22] & $\begin{array}{l}\text { CI, CII, } \\
\text { CIII, } \\
\text { CIV, CV }\end{array}$ & $128^{\circ} 08^{\prime} \mathrm{E}$ & $30^{\circ} 43^{\prime} \mathrm{N}$ & $\begin{array}{l}\text { Geological } \\
\text { dredging }\end{array}$ & Kexue Yihao & N.D. & $\begin{array}{l}\text { MDAC: mineralogical and } \\
\text { geochemical composition, } \\
\delta^{13} \mathrm{C}, \delta^{18} \mathrm{O} \text {, functional genes }\end{array}$ \\
\hline \multirow{3}{*}{$\mathrm{Xu}$ et al. [23] } & $\mathrm{C} 01$ & $127^{\circ} 19^{\prime} 55^{\prime \prime} \mathrm{E}$ & $28^{\circ} 41^{\prime} 36^{\prime \prime} \mathrm{N}$ & \multirow{3}{*}{$\begin{array}{l}\text { Gravity } \\
\text { core }\end{array}$} & \multirow{3}{*}{$\begin{array}{l}\text { Xiangyanghong } \\
\text { Ershihao }\end{array}$} & 910 & \multirow{3}{*}{$\begin{array}{l}\text { Pore water: concentrations } \\
\text { of } \mathrm{CH}_{4}, \mathrm{Na}^{+}, \mathrm{K}^{+}, \mathrm{Cl}^{-}, \mathrm{NH}_{4}+ \\
\mathrm{Mg}^{2+}, \mathrm{Ca}^{2+}, \mathrm{SO}_{4}{ }^{2-}, \delta^{13} \mathrm{C}_{\mathrm{DIC}}\end{array}$} \\
\hline & $\mathrm{C} 10$ & $127^{\circ} 21^{\prime} 17^{\prime \prime} \mathrm{E}$ & $28^{\circ} 38^{\prime} 48^{\prime \prime} \mathrm{N}$ & & & 960 & \\
\hline & $\mathrm{C} 25$ & $125^{\circ} 43^{\prime} 40^{\prime \prime} \mathrm{E}$ & $26^{\circ} 38^{\prime} 20^{\prime \prime} \mathrm{N}$ & & & 1000 & \\
\hline Guan et al. [24] & $\begin{array}{l}\text { D2, D12, } \\
\text { D30, } \\
\text { GGD5, } \\
\text { GGD16 }\end{array}$ & N.D. & N.D. & $\begin{array}{l}\text { Geological } \\
\text { dredging }\end{array}$ & Kexue Yihao & $540-700$ & $\begin{array}{c}\text { MDAC: mineral composition, } \\
\delta^{13} \mathrm{C}, \delta^{18} \mathrm{O} \\
\text { Biomarker: } \delta^{13} \mathrm{C}\end{array}$ \\
\hline Wang et al. [26] & ESC-15-08 & $126^{\circ} 50^{\prime} 34.2^{\prime \prime} \mathrm{E}$ & $27^{\circ} 56^{\prime} 27^{\prime \prime} \mathrm{N}$ & $\begin{array}{l}\text { Gravity } \\
\text { core }\end{array}$ & Haidahao & $\sim 1600$ & $\begin{array}{c}\text { MDAC: mineral composition, } \\
\delta^{13} \mathrm{C}, \delta^{18} \mathrm{O} \\
\text { Pore water: concentrations } \\
\text { of } \mathrm{SO}_{4}{ }^{2-}, \mathrm{CH}_{4}, \mathrm{Ca}^{2+}, \mathrm{Mg}^{2+}, \\
\mathrm{Sr}^{2+}, \mathrm{Ba}^{2+}, \mathrm{TA}, \mathrm{DIC}, \delta^{13} \mathrm{C}^{\text {DIC }}\end{array}$ \\
\hline Zhang et al. [49] & $\begin{array}{l}\text { W26, W31, } \\
\text { W45, W59 }\end{array}$ & N.D. & N.D. & CTD & Kexue Yihao & $\sim 900$ & $\begin{array}{l}\text { Seawater: DIC, DOC, } \\
\delta^{13} \mathrm{C}_{\mathrm{DIC}}, \delta^{13} \mathrm{C}_{\mathrm{DOC}}\end{array}$ \\
\hline Cao et al. [27] & 5GD1 & N.D. & N.D. & $\begin{array}{l}\text { Geological } \\
\text { dredging }\end{array}$ & $\begin{array}{l}\text { Xiangyanghong } \\
\text { Ershihao }\end{array}$ & 603 & $\begin{array}{l}\text { MDAC: mineral composition, } \\
\delta^{13} \mathrm{C}, \delta^{18} \mathrm{O}, \mathrm{U}-\mathrm{Th} \text { dating }\end{array}$ \\
\hline Zhang et al. [50] & 32 stations & N.D. & N.D. & CTD & Zhangjianhao & N.D. & $\begin{array}{l}\text { Seawater: temperature, } \\
\text { salinity, concentration } \\
\text { of } \mathrm{CH}_{4}\end{array}$ \\
\hline \multirow{4}{*}{ Li et al. [16] } & D1 & N.D. & N.D. & \multirow{4}{*}{$\begin{array}{l}\text { Seafloor } \\
\text { drilling }\end{array}$} & \multirow{4}{*}{ Haidahao } & 965 & \multirow{4}{*}{$\begin{array}{l}\text { Pore water: concentrations } \\
\text { of } \mathrm{SO}_{2-}^{4}, \mathrm{CH}_{4}, \delta^{13} \mathrm{C}_{-} \mathrm{CH}_{4} \\
\qquad \mathrm{DD}-\mathrm{CH}_{4}\end{array}$} \\
\hline & $\mathrm{D} 2$ & N.D. & N.D. & & & 1047 & \\
\hline & D4 & N.D. & N.D. & & & 1048 & \\
\hline & D5 & N.D. & N.D. & & & 921 & \\
\hline \multirow{8}{*}{$\mathrm{Xu}$ et al. [28] } & $\mathrm{R} 3-\mathrm{C} 1$ & N.D. & N.D. & & & 953 & \multirow{8}{*}{$\begin{array}{l}\text { Pore water: concentrations } \\
\text { of } \mathrm{CH}_{4}, \mathrm{Cl}^{-}, \mathrm{Br}^{-}, \mathrm{SO}_{4}^{2-} \\
\mathrm{Na}^{+}, \mathrm{Li}^{+}, \mathrm{Mg}^{2+}, \mathrm{Ca}^{2+}, \mathrm{Sr}^{2+} \\
\mathrm{NH}_{4}^{+}, \mathrm{DIC}, \delta^{13} \mathrm{C}_{\mathrm{DIC}} \\
\delta^{13} \mathrm{C}-\mathrm{CH}_{4}, \delta \mathrm{D}-\mathrm{CH}_{4}\end{array}$} \\
\hline & R3-C2 & N.D. & N.D. & & & 957 & \\
\hline & $\mathrm{R} 4-\mathrm{C} 2$ & N.D. & N.D. & ROV push & & 924 & \\
\hline & $\mathrm{R} 4-\mathrm{C} 4$ & N.D. & N.D. & core & & 922 & \\
\hline & R6-C1 & N.D. & N.D. & & 11100 & 913 & \\
\hline & $\mathrm{R} 6-\mathrm{C} 4$ & N.D. & N.D. & & & 915 & \\
\hline & G08 & N.D. & N.D. & \multirow{2}{*}{$\begin{array}{l}\text { Gravity } \\
\text { core }\end{array}$} & & 1020 & \\
\hline & G04 & N.D. & N.D. & & & 958 & \\
\hline
\end{tabular}

N.D.: not documented. 


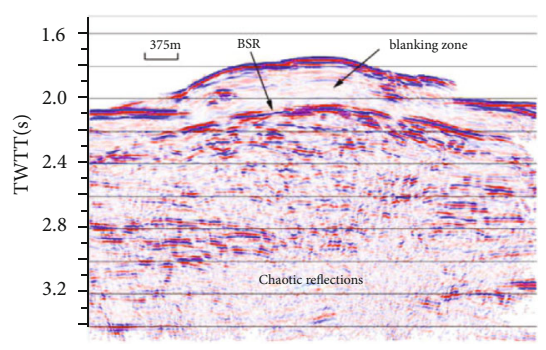

(a)

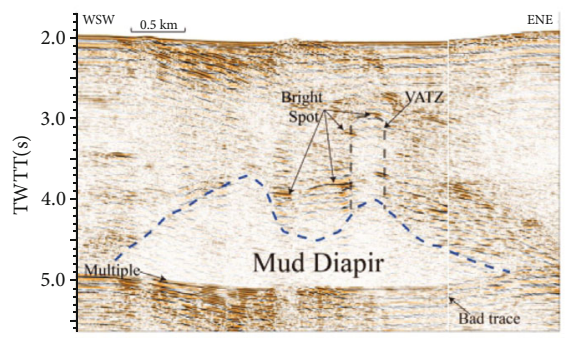

(b)

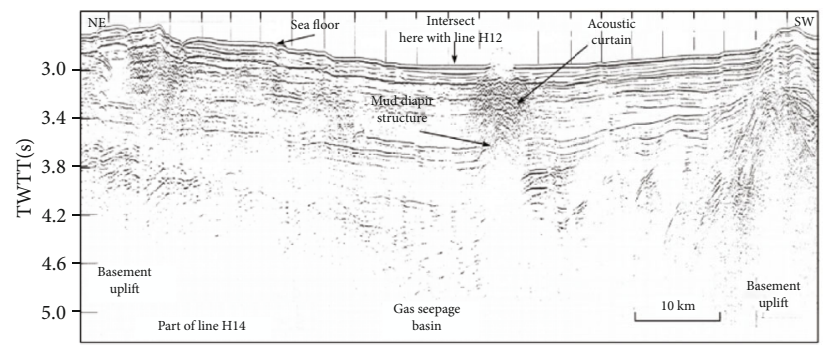

(c)

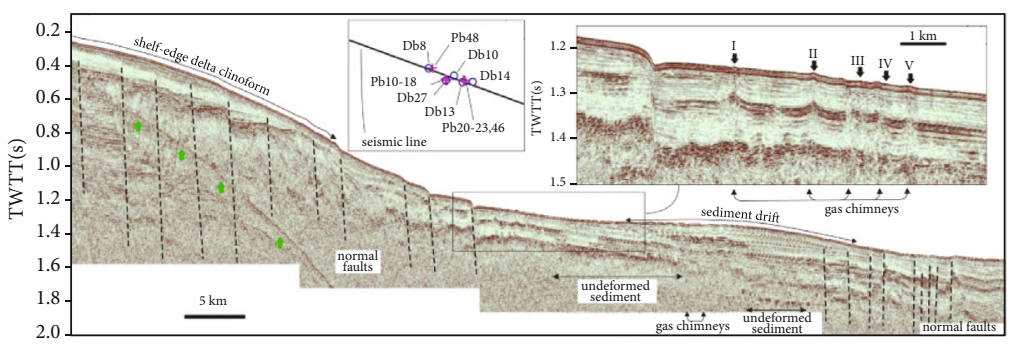

(d)

FIgURE 3: The representative seismic sections in the Okinawa Trough showing the features associated with the vertical migration pathways for the methane-rich pore fluids. (a) Blanking zone and mud diapir (from [11]). (b) Bright spot and mud diapir (from [12]). (c) Acoustic curtain and mud diapir (from [10]). (d) Gas chimney (from [16]).

understand the entire process of methane transport in the subsurface before seeping on the seabed.

2.2. Geomorphological Features. Minor topographic highs of different dimensions have been acoustically detected in the OT, including tens of the conical [16], some ridge-like [15] (Figures 4(a) and $4(\mathrm{~b})$ ), and $\sim 2 \mathrm{~km}$ wide positive reliefs [11]. Interestingly here, there have been few reports of pockmark, a well-known bathymetric depression in the region of vigorous gas venting [12, 37]. Their formation is mostly associated with the expulsion of focused fluid flow, while a few of them are caused by diapirism and magma intrusion [37]. The morphologies of part of the small reliefs, including the height, the width, and the gradient of the flank, are comparable with those of the submarine mud volcanos in other oceans [38]. However, there has been no solid evidence to confirm the presence of mud volcano in the OT, such as the mud-rich liquified sediments outflowing from the apex of the relief [39] or the mud breccia carried through the sedimentary successions and subsequently embedded within the migration conduits [40]. The distribution of some of the seepage-related reliefs seems to be close to the faults extending to the seabed, though some others are not and their alignment is not subparallel with the strike of most of the faults [16]. The factor controlling the deformation of the near-seafloor sediments in the OT is not clear. The abovementioned geomorphological features alone are not a robust indicator of methane seepages because multiple geological processes can potentially shape the bathymetry, such as the hydrothermal venting and the erosion of bottom currents [41].

2.3. Hydroacoustic Flares. More than three hundred hydroacoustic flares have been detected to scatter along the western margin of the OT $[16,25]$. They emanate from the domed or relatively flat seabed at the water depth of $<1500 \mathrm{~m}$, propagating through the water column by hundreds of meters [16]. The backscattering intensities within them often peak at the center of their lower part and decrease upwards and outwards [16]. These intensity variations with space make an outer rim surrounding the flare on the acoustic curtain of the echo-sounder data. The occurrence of the gas flares indicates the rapid and probably ephemeral expulsion of free gas bubbles escaping from the seabed. The tops of the acoustic flares rarely reach close to the sea surface, suggesting that the expulsed methane is in dissolved form in the seawater column and thus its direct release into the atmosphere may be negligible. As for the geometries of the acoustic flares, 


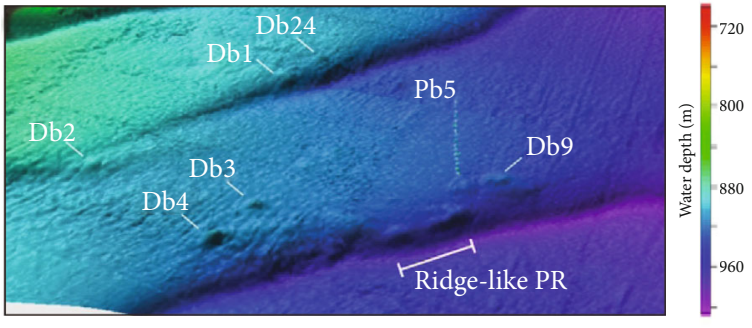

(a)

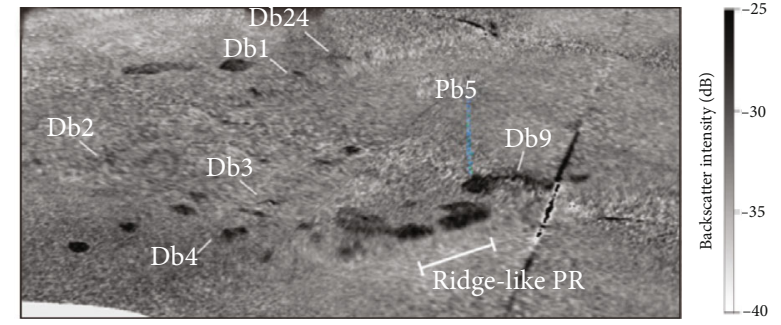

(b)

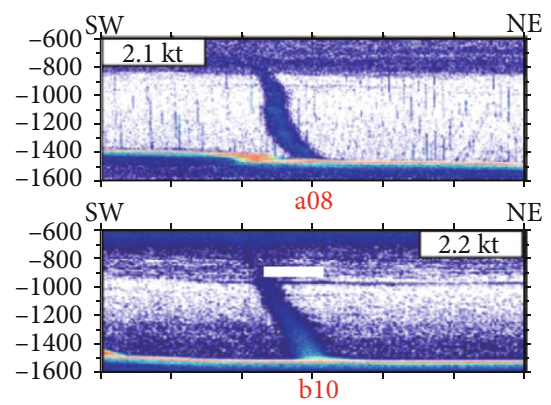

(d)

FIgURE 4: The morphological and hydroacoustic features surrounding the cold seeps of the Okinawa Trough. (a, b) Dome-like and ridge-like positive reliefs and their nearby backscattering features at the level of the seabed (modified from [15]). (c) Acoustic flares above the cold seeps (from [16]). (d) Gas plumes indicating the escape of free gases from marine sediments (from [14]).

they are similar in previous studies and characterized by substraight or curved flare-like columns [14-16] (Figures 4(c) and 4(d)). The rising direction of the free gas bubbles bounded by the acoustic flares was thought to be affected by the bottom current, and a simple 2-D model of velocity component has been put forward to give the first approximation of its speed. The results show that the velocity of the bottom current is $2-160 \mathrm{~cm} / \mathrm{s}$ in submarine volcanic areas and $20-50 \mathrm{~cm} / \mathrm{s}$ in the scarcely undulating seabed [14]. The deflection of the trajectory of the ascending free gas bubbles could also be attributed to the configuration of the overpressure and the openings near the seabed. The dendritic cluster of the acoustic flares observed in the MOT reveals that the gas flares have similar lateral shifts after leaving the domed seabed [16] (the vertical exaggeration of their figures is too high to observe the tilting). This suggests that the pressure gradient at different directions in plan view should be similar.

\section{Geochemical Constraints}

3.1. Origin of Methane. The origin of methane surrounding the recent seeping sites has been determined from the carbon and hydrogen isotope values $\left(\delta^{13} \mathrm{C}_{\mathrm{CH}_{4}}\right.$ and $\left.\delta \mathrm{D}_{\mathrm{CH}_{4}}\right)$ of the headspace gases sampled from piston and $\mathrm{ROV}$ push cores (7 $\mathrm{m}$ and $35 \mathrm{~cm}$ long, respectively, Figure 5) [28] and seafloor drill cores (55 m long, Figure 5) [16]. The results of the isotopic analysis of the pore water show that the methane in the shallow sediments was generated via the microbially mediated processes of carbon dioxide reduction $\left(\delta^{13} \mathrm{C}_{\mathrm{CH}_{4}}<-50 \%\right.$, microbial methane) and/or thermal cracking of organic matter $\left(\delta^{13} \mathrm{C}_{\mathrm{CH}_{4}}>-50 \%\right.$, thermogenic

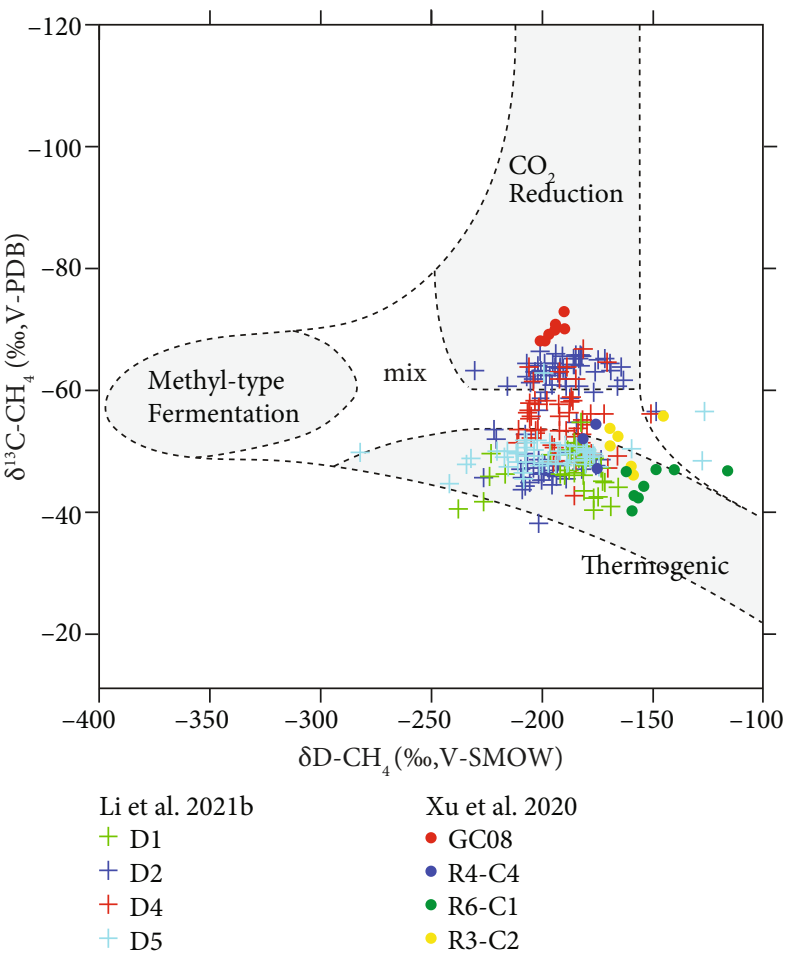

FIgURE 5: C-D diagram $\left(\delta^{13} \mathrm{C}_{\mathrm{CH}_{4}}\right.$ vs. $\left.\delta \mathrm{D}_{\mathrm{CH}_{4}}\right)$ indicating methane sources. The grey areas indicate fields for microbial and thermogenic endmembers after [54, 55].

methane) $[16,28]$. These results seem to agree with the summary of the origin of methane-rich natural gas in the backarc region of active magmatism in the southernmost end of the OT [42] and the Western Pacific [43]. However, its 


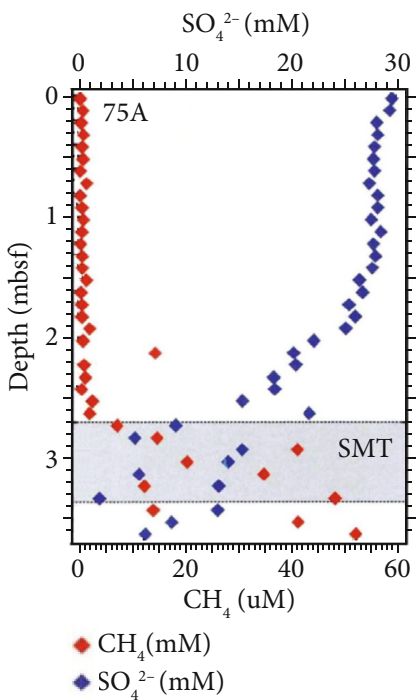

(a)

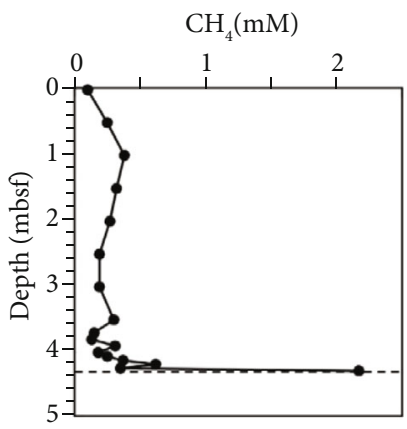

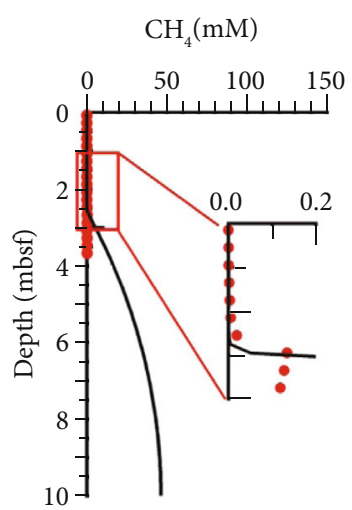

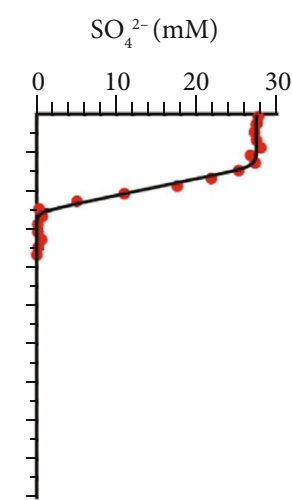

(b)

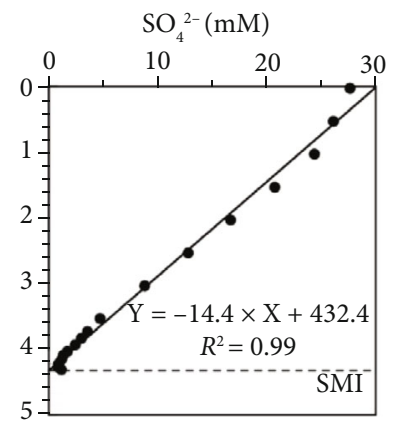

(c)

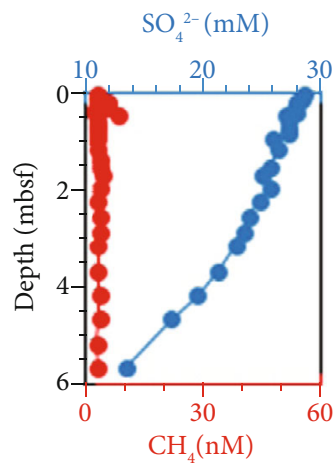

(d)

FIGURE 6: The depth profiles of the concentrations of $\mathrm{CH}_{4}$ and $\mathrm{SO}_{4}{ }^{2-}$ of the pore waters. They show relatively shallow SMTZ depths. (a) Core-75A (from [21]). (b) CG08 (from [28]). (c) ESC-15-08 (from [26]). (d) C25 (from [23]). Their locations can be found in Figure 2(b).

thermogenic origin is not observed in the NOT, in which the isotopic analysis of authigenic carbonates supports the predominance of the microbial methane in the past seeping activity [24]. We think the data published till now would not suffice to fully understand this origin in the OT. A supplement of the data of the composition of $\mathrm{C}_{2+}$ hydrocarbon gases and $\delta^{13} \mathrm{C}_{\mathrm{DIC}}$ will make the conclusion of the origin more convincing. It is difficult to determine the depth ranges of the horizons within which the methanogenesis occurred due to the lack of information on the borehole drilling (there is an exploration well of TO-KA-1 but no source rock has been reported) [44]. A simple generation window of light hydrocarbon gas in the MOT is estimated by using the in situ measured seafloor heat flux. The depth ranges of $\leq 662 \mathrm{mbsf}$ for microbial methane and $815-1899 \mathrm{mbsf}$ for thermogenic ones are shallower than most of the marginal basins in the Northwestern Pacific due to its higher geothermal gradient $\left(114-187^{\circ} \mathrm{C} / \mathrm{km}\right)$ [16].

3.2. Pore Water. The pore waters are one of the important geological records for temporal methane seepage and their analysis would help in understanding what happened to it at present. Its geochemistry has been analyzed to support the upward diffusive fluxes of the dissolved methane, the dissolved inorganic carbon (DIC), and the precipitation rate and quantitatively investigate the carbon cycling. The depth of the sulfate-methane transition zone (SMTZ) of use in, understanding the intensity of methane seepage in the preliminary study [45]. Most of the SMTZ depths in the OT are $<20 \mathrm{~m}$ at the coring sites [21, 23, 26, 28] (Figure 6), which suggests the weak-medium methane seepage. The diffusive fluxes were further determined by numerical modeling, and the results reveal the medium intensities near the fault scarp $\left(130 \mathrm{mmol} \mathrm{m}^{-2} \mathrm{yr}^{-1}\right)$ and the canyons $\left(20.7 \mathrm{mmol} \mathrm{m}^{-2} \mathrm{yr}^{-1}\right)$ and the high intensities in the vicinity of the seabed domes $\left(515-6450 \mathrm{mmol} \mathrm{m}^{-2} \mathrm{yr}^{-1}\right)[23,28]$. Part of the dissolved methane ( 12\%-66\%) [28] was discharged from the seabed after passing through the filter of the sediment column, in which most of the methane was consumed by the biogeochemical process of anaerobic oxidation of methane (AOM). The AOM is often predominant in the study area (e.g., C25 [23]), while the integrated rates of the organoclastic sulfate reduction are larger at some sites (e.g., R3-C1 [28]). The results of the reaction-transport modeling 


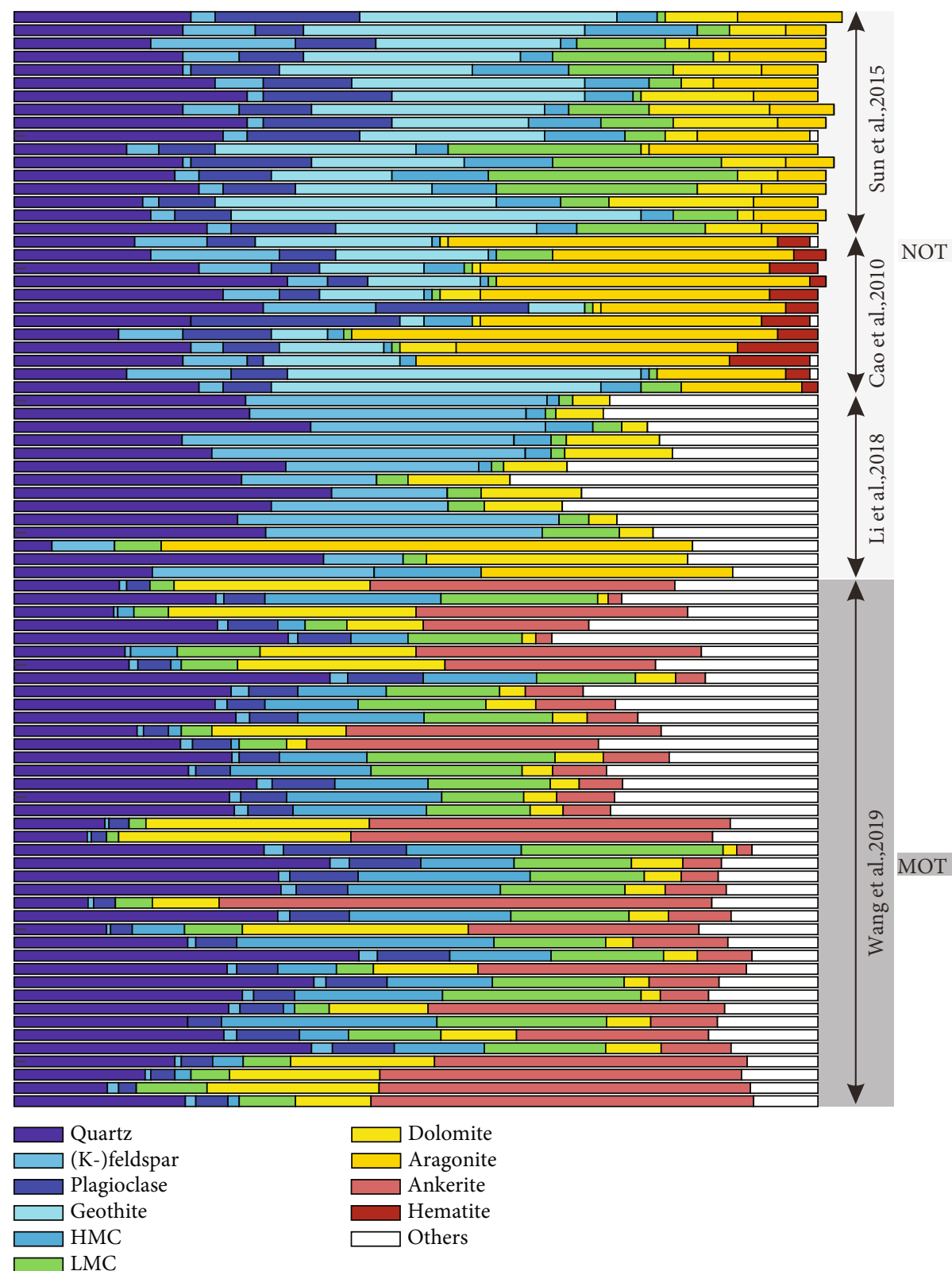

FIGURE 7: The mineralogical compositions of the MDACs in the northern and the middle Okinawa Trough (NOT and MOT, respectively).

show that the AOM rates in the Mid-Okinawa Trough vary by three orders of magnitude, with a maximum of $2197 \mathrm{mmol} \mathrm{m}^{-2} \mathrm{yr}^{-1}$ near a dome (DS3) [28].

The carbonate precipitation lowered the permeability and buffered the seeping of the dissolved methane into the water column [46]. Apart from being a physical barrier for ascending pore fluids, it can also recycle methane by AOM. It has been estimated that most of the upward diffusive methane $\left(20.7 \mathrm{mmol} \mathrm{m}^{-2} \mathrm{yr}^{-1}\right)$ was oxidized into DIC $\left(11.2 \mathrm{mmol} \mathrm{m}^{-2} \mathrm{yr}^{-1}\right)$ within the SMTZ, while the rest was incorporated into the authigenic carbonates $\left(9.4 \mathrm{mmol} \mathrm{m}^{-}\right.$ ${ }^{2} \mathrm{yr}^{-1}$ ) at site C25 in the MOT [23]. The alkaline earth elemental compositions of pore waters provide information on the environment in which different carbonates are precipitating [47]. The concentrations of $\mathrm{Mg}^{2+}, \mathrm{Ca}^{2+}$, and $\mathrm{Sr}^{2+}$ and their ratios have been used to predict the types of precipitating carbonate minerals. The precipitation of high$\mathrm{Mg}$ calcite and aragonite likely occurs in the MOT [28], and such minerals have been found in the NOT [27]. Further examining this role of the geochemistry of pore waters requires the in situ carbonate cores retrieved at the seafloor drilling sites.

3.3. Methane-Derived Authigenic Carbonates. Methanederived authigenic carbonates (MDAC) are considered as a useful paleoenvironmental archiver in studying the seeping event because they yield information of the redox state of oceans and the evolution of biogeochemical processes through geological time [48]. The study of the MDAC in the OT focuses on the mineralogical composition, the major 


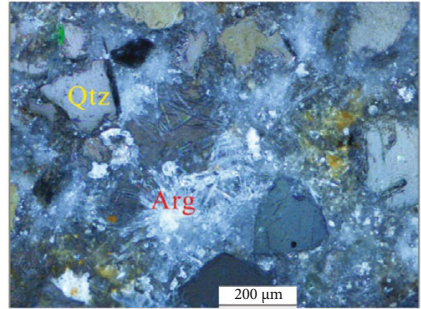

(a)

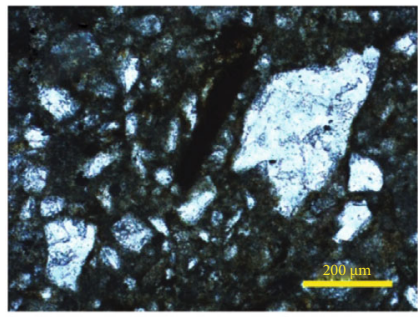

(d)

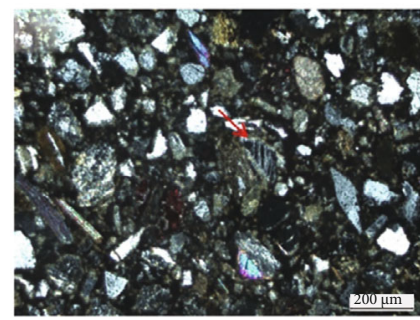

(g)

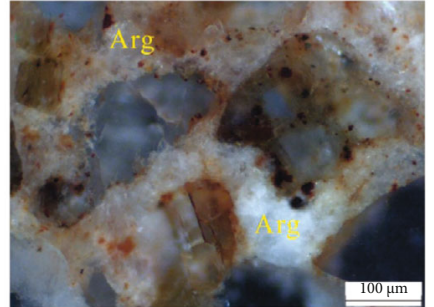

(b)

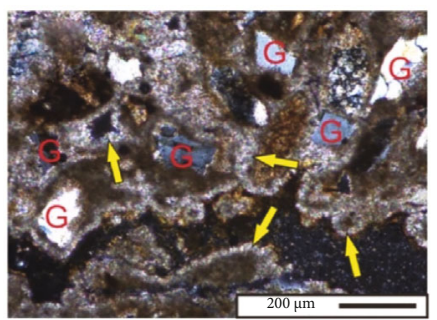

(e)

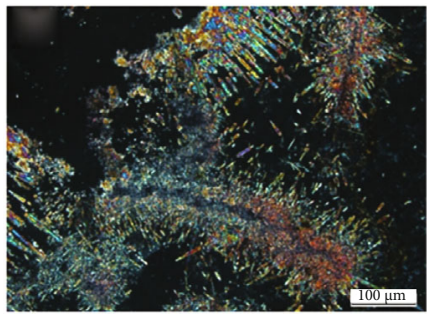

(h)

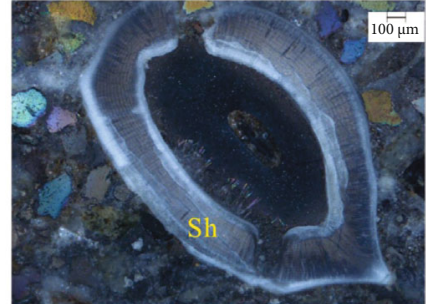

(c)

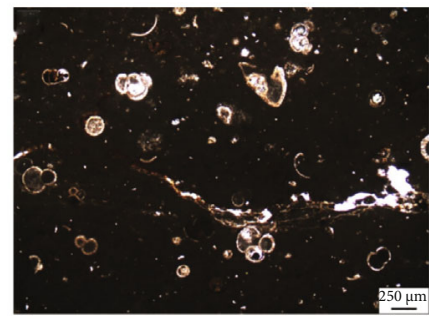

(f)

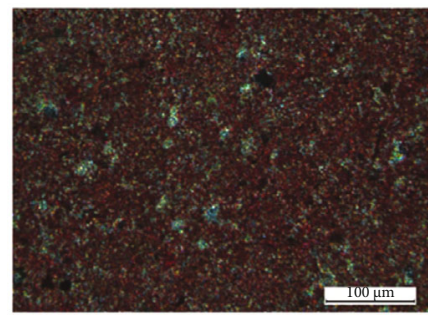

(i)

FIgURE 8: Thin-section microphotos of the carbonate samples in the Okinawa Trough. (a) Radial fibrous aragonite crystals (transmitted polarized light). (b) Antigenic carbonate stained by brown goethite (reflected polarized light). (c) Well-preserved shell fragments (Sh) cemented by microcrystalline aragonite (transmitted polarized light). Qtz: quartz; Arg: aragonite. Panels (a-c) are from [27]. (d) Typical features of inequigranular texture and angular shapes within the carbonate chimney (from [18]). (e) Angular grains (G) surrounded by authigenic carbonates and stained by Fe oxide. The early microlite carbonates are immediately encircled by the later bright carbonate rims (marked by yellow arrows, from [25]). (f) Typical features of the carbonate matrix of the cored samples (from [19]). (g) Feldspar replaced by micritic dolomite. (h) Acicular aragonite replaced by micritic dolomite. (i) Aragonite cement in the crust. Panels (g-i) are from [22].

and rare elements, the isotopes (carbon, oxygen, sulfur), and the microbial community, in an attempt to understand the origin and the sources of pore fluids and, more importantly, reconstruct the biogeochemical processes in the seep environment [18-20, 22, 27]. The mineral compositions of these carbonates are mainly aragonite, magnesium-rich calcite, and dolomite (Figures 7 and 8). Fe-rich minerals exist in the form of goethite and hematite in the NOT and ankerite in the MOT $[18,22,26,27]$. The minerals and the biomarker patterns indicate that the MDAC formed at depth in an environment of low-to-medium flux of methane [24]. Some reasonable explanations concerning the origin of methanerich fluids were provided based on $\delta^{13} \mathrm{C}$ and $\delta^{18} \mathrm{O}$ values of the seep carbonates (Figure 9). The methane sustaining the carbonate precipitation through AOM probably has a microbial origin based on $\delta^{13} \mathrm{C}$ values of the seep carbonates $<-60 \%$, and this methane might be originated from the dissociation of the gas hydrates [24, 27]. This inference is inconsistent with the results of the pore waters, which point towards the minor contributions of the methane hydrate dissociation to feeding the methane seepage [28]. Parts of seep carbonate $\delta^{13} \mathrm{C}$ values are relatively high and thought to derive from the admixtures of normal marine DIC. An alternative explanation for these values is a mixture of methane-derived diagenetic carbonates and detrital origin ones in different parts of the sampled carbonates [22].

Three subhorizontal zones of the oxidizing zone (OZ), the sulfate-methane transition zone (SMTZ), and the sulfate-depleted zone (SDZ) in the seep environment have been built to discuss the biogeochemical processes in the OT [22]. The two latter zones have been investigated in detail, in which the important processes include methanogenesis, methane oxidation, sulfite oxidation, sulfate reduction, and metal biotransformations [20, 22]. The microbial populations supporting these biogeochemical processes have been detected by the GeoChirp analysis, the results of which reveal the functional genes related to the cycling of methane, sulfur, and iron [22]. AOM can increase the saturation state of carbonate minerals and the alkalinity of pore waters and provides chemical energy for benthic ecosystems $[6,9]$. 


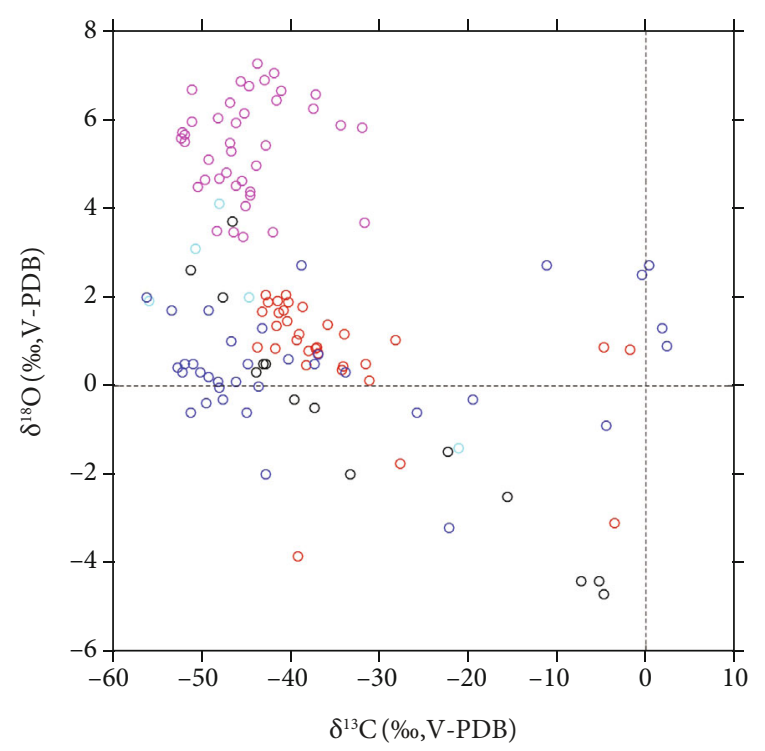

o Sun et al., 2015

o Li et al., 2018

Guan et al., 2019

- Wang et al., 2019

o Cao et al., 2020

FIgURE 9: The diagram of the documented $\delta^{13} \mathrm{C}$ and $\delta^{18} \mathrm{O}$ values of seep carbonates in the Okinawa Trough.

The Fe-rich carbonates sampled in the NOT (GT-D1) well record such processes, including the sulfate-driven AOM $(\mathrm{SD}-\mathrm{AOM})$ and the suggested Fe-driven AOM [22]. The pyrite that extensively occurs within the seep carbonates at the bottom of the SDZ underlain by the Fe-driven AOM zone. The sources of iron and sulfur from the pyrite formation are proposed to be the products of Fe-driven AOM and SD-AOM, respectively $[20,22]$. Apart from being a reactant in SD-AOM, sulfate determines the types of carbonates. High, medium, and low concentrations of sulfate in pore waters provide potential conditions for the formation of aragonite, magnesium-calcite, and dolomite, respectively [22].

3.4. Water Column. The studies of the seawater in the OT are aimed at pinpointing the sites of the enhanced concentration of dissolved methane, assessing the origin of the carbon, and figuring out the methane flux at the sedimentseafloor and the sea-air interfaces $[42,49,50]$. The most important contributors to the dissolved carbon in the seawater are hydrothermal vents and cold seeps, and the DIC through the latter ones constitutes up to $14.3 \%$ of the total amount in the seawater [49]. The enhanced concentration of the dissolved methane was detected in the western slope of the MOT, and the value of $24.7 \mathrm{nM}$ is ten times higher than the background concentration [50]. The sea-to-air flux of methane can reach up to $116 \mu \mathrm{mol} \mathrm{m}^{-2} \mathrm{~d}^{-1}$, and the average values higher than those in other known oceans indicate the MOT is rich in methane, which discharges into the seawater and even the atmosphere from the seabed at present [50].

\section{The Impact of Hydrothermal Activities on Methane Seeps}

The Okinawa Trough is a narrow, elongated incipient backarc basin rich in hydrothermal vents $[29,51]$. The geological setting of the laterally restricted environment allows the transfer of metal oxides from the hydrothermal regions near the back-arc rifting center to the seeping areas along the western slope. $\mathrm{Fe}$ and $\mathrm{Mn}$ vented by intermittent hydrothermal activities had been oxidized and precipitated during its plume dispersal and eventually mixed with the surface sediments in the form of the particle rain in the oxygenated seawater [25]. As a result, there will be sufficient metal supply within the shallow marine sediments at some seeping sites. The metal oxides sourced from the hydrothermal activity can be the reactive oxidants of AOM, in addition to the sulfate derived from the seawater. Their coexistence contributes to the unique features of the seep carbonates in the OT. The ongoing reactions of SD-AOM and Fe-AOM and their vertically neighboring reaction zones have been confirmed by high iron contents $(3.77-12.49 \%)$ in carbonate chimney, the presence of goethite, siderite, and pyrite precipitating within the MDAC, and more importantly, the functional genes related to iron storage and transport by using GeoChirp analysis $[18,20,22,25] . \mathrm{Fe}^{2+}$ and $\mathrm{HS}^{-}$, which are the products of $\mathrm{Fe}-\mathrm{AOM}$ and $\mathrm{SD}-\mathrm{AOM}$, respectively, could meet each other near the interface of these zones and lead to the precipitation of the pyrite-rich carbonate pipes [20]. It is proposed that metal-AOM and sulfate-AOM together constitute an important part of the benthic methane filter and act to regulate the carbon cycle [25].

\section{Timing and Evolution of Cold Seeps}

The methane seeps are thought to be active recently and thousands of years ago. The former active timing can be indicated by the observation of the widespread gas plumes in 2012-2018 in the SOT [14] and 2013-2016 in the MOT $[15,16]$. The free gas bubbles bypassed the sedimentary succession and sustained the seeps. This vertical migration is favored by the tectonically active setting, including the regional continuing tension and transtension $[15,16]$. The resultant-enhanced permeability and the excess pore pressure promote the upward migration of free methane gases along the fault zone and the clusters of fractures, respectively. However, it is difficult to determine the longevity of recently active seeps due to the limitation of the transient time of geophysical information. The MDACs sampled at the seabed also archive the active timing of the past methane seepages. AMS ${ }^{14} \mathrm{C}$ and U-Th dating results show that the age ranges of the seep carbonates are $31.54-34.10 \mathrm{kyrs} B P$ and 22.8-55.7 kyrs BP, respectively $[18,27]$. Similar to other oceans, the OT underwent the relative sea-level drop during these periods $[52,53]$. This may lead to the thinning of the gas hydrate stability zone, and thus, the abundant free gases liberated from the gas hydrate would get involved in the AOM, which offers a proper geochemical environment for carbonate precipitation. Nevertheless, the link between the 
seep and the gas hydrate during sea-level lowstands and highstands in the OT has not been conclusive yet.

\section{Outlook}

The methane seeps in the Okinawa Trough were discovered by geological surveys in the last two decades. The support of these cruises and the national and international research projects leads to the advancement of the understanding of the methane seepage in the deep-water settings of the Okinawa Trough. Continuing studies focused on some seeping sites and provide good targets for subsequent studies. These results shed light on the activity of methane seepages, associated biogeochemical processes, and material cycling mostly within the shallow lithosphere and the deep hydrosphere.

The progress brought by the studies reviewed in this paper is promising, and yet future challenges await. To our knowledge, further research supported by the integrated coring program in the Okinawa Trough is underway. This research together with the forthcoming multidisciplinary ones will help to answer the unsolved yet important questions, including but not limited to (1) whether or not the seabed domes are mud volcanoes should be confirmed. This could be achieved by obtaining the mud breccia-containing sediment core through the conduit of the seabed cone. This is of importance in figuring out the composition and the phase of the transported sediments; (2) from where and how the methane-rich gases were vented; (3) whether or not the dissociation of methane hydrate contributed to the activity of gas seepage, answering (2) and (3) partly depends on the use of 3-D high-resolution seismic data that can image the entire plumbing system and show the anomaly of the seismic reflection (e.g., bottom simulating reflector) surrounding the seeps; (4) what is the temporal change of the flux of free methane gas at the seabed. Long-term seafloor monitoring is a useful technique for this, offering first-hand measurement results as a requisite in evaluating the impact of seeps on climatic change; (5) how the seeps evolved and the accompanying biogeochemical processes varied in the past. Their answers require an in-depth study of more in situ authigenic minerals and will make the submarine seep a solid geological record of the global climatic change; (6) what is the ecosystem surrounding the seeps and how the community interacts with each other. The answer to this rarely studied subject will ultimately explain mass cycling in the seeping system of the Okinawa Trough.

The methane seeps in the Okinawa Trough are unique, characterized by young age and Fe enrichment due to the incipient back-arc rifting and the abundant hydrothermal vents. This geology offers an excellent natural laboratory to study the deep-water methane seeps. As the joint and multidisciplinary research continues, it is believed that the nature of methane seepage and its influences in the global climatic change in history and at present will eventually be understood.

\section{Conflicts of Interest}

The authors declare that they have no conflicts of interest.

\section{Acknowledgments}

This research is supported by the projects of the National Key R\&D Program of China (2018YFC0310001), the National Natural Science Foundation of China (91858208 and 42006066), and the Shandong Provincial Natural Science Foundation, China (ZR201807100270).

\section{References}

[1] A. R. Talukder, "Review of submarine cold seep plumbing systems: leakage to seepage and venting," Terra Nova, vol. 24, no. 4, pp. 255-272, 2012.

[2] E. Suess, "Marine cold seeps and their manifestations: geological control, biogeochemical criteria and environmental conditions," International Journal of Earth Sciences, vol. 103, no. 7, pp. 1889-1916, 2014.

[3] D. Feng, H. H. Roberts, H. Cheng et al., "U/Th dating of coldseep carbonates: an initial comparison," Deep Sea Research Part II: Topical Studies in Oceanography, vol. 57, no. 21-23, pp. 2055-2060, 2010.

[4] L. H. King and B. MacLean, "Pockmarks on the Scotian shelf," Geological Society of America Bulletin, vol. 81, no. 10, pp. 3141-3148, 1970.

[5] A. G. Judd, "The global importance and context of methane escape from the seabed," Geo-Marine Letters, vol. 23, no. 3-4, pp. 147-154, 2003.

[6] S. E. Ruff, J. F. Biddle, A. P. Teske, K. Knittel, and A. Ramette, "Global dispersion and local diversification of the methane seep microbiome," Proceedings of the National Academy of Sciences of the United States of America, vol. 112, no. 13, pp. 4015-4020, 2015.

[7] A. Biastoch, T. Treude, L. H. Rüpke et al., "Rising Arctic Ocean temperatures cause gas hydrate destabilization and ocean acidification," Geophysical Research Letters, vol. 38, no. 8, 2011.

[8] A. Crémière, A. Lepland, S. Chand et al., "Timescales of methane seepage on the Norwegian margin following collapse of the Scandinavian Ice Sheet," Nature Communications, vol. 7, no. 1, pp. 1-10, 2016.

[9] W. S. Reeburgh, "Oceanic methane biogeochemistry," Chemical Reviews, vol. 107, no. 2, pp. 486-513, 2007.

[10] X. Luan and Y. Qin, "Gas seepage on the sea floor of Okinawa Trough Miyako Section," Chinese Science Bulletin, vol. 50, no. 13, pp. 1358-1365, 2005.

[11] N. Xu, S. Wu, B. Shi et al., "Gas hydrate associated with mud diapirs in southern Okinawa Trough," Marine \& Petroleum Geology, vol. 26, no. 8, pp. 1413-1418, 2009.

[12] J. Xing, X. Jiang, and D. Li, "Seismic study of the mud diapir structures in the Okinawa Trough," Geological Journal, vol. 51, pp. 203-208, 2016.

[13] D. Li, H. Chen, S. Xu, J. Xing, H. Cheng, and J. Wang, "Stratigraphic sequence and sedimentary systems in the middlesouthern continental slope of the East China Sea from seismic reflection data: exploration prospects of gas hydrate," Journal of Ocean University of China, vol. 18, no. 6, pp. 1302-1316, 2019.

[14] C.-H. Tsai, S.-K. Hsu, Y.-F. Chen et al., "Gas plumes and nearseafloor bottom current speeds of the southernmost Okinawa Trough determined from echo sounders," Terrestrial, Atmospheric, Oceanic Sciences, vol. 30, no. 5, pp. 649-674, 2019. 
[15] A. Li, F. Cai, N. Wu et al., "Gas emissions in a transtensile regime along the western slope of the Mid-Okinawa Trough," Earth Sciences, vol. 9, no. 31, 2021.

[16] A. Li, F. Cai, N. Wu et al., "Structural controls on widespread methane seeps in the back-arc basin of the Mid-Okinawa Trough," Ore Geology Reviews, vol. 129, no. 103950, pp. 1$15,2021$.

[17] Q. Li, F. Cai, J. Liang et al., "Geochemical constraints on the methane seep activity in western slope of the middle Okinawa Trough, the East China Sea," Science China Earth Sciences, vol. 58, no. 6, pp. 986-995, 2015.

[18] Z. Sun, H. Wei, X. Zhang et al., "A unique Fe-rich carbonate chimney associated with cold seeps in the Northern Okinawa Trough, East China Sea," Deep-Sea Research Part I, vol. 95, pp. 37-53, 2015.

[19] M. Wang, F. Cai, Q. Li et al., "Characteristics of authigenic pyrite and its sulfur isotopes influenced by methane seep at core A, site 79 of the middle Okinawa Trough," Science China Earth Sciences, vol. 58, no. 12, pp. 2145-2153, 2015.

[20] X. Peng, Z. Guo, S. Chen et al., "Formation of carbonate pipes in the northern Okinawa Trough linked to strong sulfate exhaustion and iron supply," Geochimica et Cosmochimica Acta, vol. 205, pp. 1-13, 2017.

[21] Q. Li, F. Cai, G. Yan et al., "Widespread methane seep activities along the western slope of the Okinawa Trough, East China Sea," Acta Geologica Sinica, vol. 91, no. 4, pp. 1505-1506, 2017.

[22] J. Li, X. Peng, S. Bai, Z. Chen, and J. D. V. Nostrand, "Biogeochemical processes controlling authigenic carbonate formation within the sediment column from the Okinawa Trough," Geochimica et Cosmochimica Acta, vol. 222, pp. 363-382, 2018.

[23] C. Xu, N. Wu, Z. Sun et al., "Methane seepage inferred from pore water geochemistry in shallow sediments in the western slope of the Mid-Okinawa Trough," Marine and Petroleum Geology, vol. 98, pp. 306-315, 2018.

[24] H. Guan, Z. Sun, S. Mao et al., "Authigenic carbonate formation revealed by lipid biomarker inventory at hydrocarbon seeps: a case study from the Okinawa Trough," Marine and Petroleum Geology, vol. 101, pp. 502-511, 2019.

[25] Z. Sun, N. Wu, H. Cao et al., "Hydrothermal metal supplies enhance the benthic methane filter in oceans: an example from the Okinawa Trough," Chemical Geology, vol. 525, pp. 190209, 2019.

[26] M. Wang, Q. Li, F. Cai et al., "Formation of authigenic carbonates at a methane seep site in the middle Okinawa Trough, East China Sea," Journal of Asian Earth Sciences, vol. 185, article 104028, 2019.

[27] H. Cao, Z. Sun, N. Wu et al., "Mineralogical and geochemical records of seafloor cold seepage history in the northern Okinawa Trough, East China Sea," Deep Sea Research Part I: Oceanographic Research Papers, vol. 155, article 103165, 2020.

[28] C. Xu, N. Wu, Z. Sun et al., "Assessing methane cycling in the seep sediments of the mid-Okinawa Trough: insights from pore-water geochemistry and numerical modeling," Ore Geology Reviews, vol. 129, no. 103909, pp. 1-11, 2020.

[29] M. Kimura, "Back-arc rifting in the Okinawa Trough," Marine and Petroleum Geology, vol. 2, no. 3, pp. 222-240, 1985.

[30] W. Zhang, J. Liang, J. Lu et al., “Accumulation features and mechanisms of high saturation natural gas hydrate in Shenhu Area, northern South China Sea," Petroleum Exploration and Development, vol. 44, no. 5, pp. 708-719, 2017.
[31] J. Wei, J. Li, T. Wu et al., "Geologically controlled intermittent gas eruption and its impact on bottom water temperature and chemosynthetic communities-a case study in the "HaiMa" cold seeps, South China Sea," Geological Journal, vol. 55, no. 9, pp. 6066-6078, 2020.

[32] T. Wu, J. Wei, S. Liu et al., "Characteristics and formation mechanism of seafloor domes on the north-eastern continental slope of the South China Sea," Geological Journal, vol. 55, no. 1, pp. 1-10, 2020.

[33] R. J. Davies and S. A. Stewart, "Emplacement of giant mud volcanoes in the South Caspian Basin: 3D seismic reflection imaging of their root zones," Journal of the Geological Society, vol. 162, no. 1, pp. 1-4, 2005.

[34] A. L. Anderson and L. D. Hampton, "Acoustics of gas-bearing sediments I. Background," The Journal of the Acoustical Society of America, vol. 67, no. 6, pp. 1865-1889, 1980.

[35] J. Cartwright and C. Santamarina, "Seismic characteristics of fluid escape pipes in sedimentary basins: implications for pipe genesis," Marine and Petroleum Geology, vol. 65, pp. 126-140, 2015.

[36] L. Rass, N. S. C. Simon, and Y. Y. Podladchikov, "Spontaneous formation of fluid escape pipes from subsurface reservoirs," Scientific Reports, vol. 8, no. 1, pp. 1-11, 2018.

[37] M. Hovland and A. G. Judd, Seabed Pockmarks and Seepages: Impact on Geology, Biology and the Marine Environment, Graham \& Trotman, 1988.

[38] L. Somoza, R. Leon, M. Ivanov et al., "Seabed morphology and hydrocarbon seepage in the Gulf of Cadiz mud volcano area: acoustic imagery, multibeam and ultra-high resolution seismic data," Marine Geology, vol. 195, no. 1-4, pp. 153-176, 2003.

[39] M. Rovere, F. Gamberi, A. Mercorella et al., "Venting and seepage systems associated with mud volcanoes and mud diapirs in the southern Tyrrhenian Sea," Marine Geology, vol. 347, pp. $153-171,2014$.

[40] A. Mazzini and G. Etiope, "Mud volcanism: an updated review," Earth-Science Reviews, vol. 168, pp. 81-112, 2017.

[41] D. Palomino, N. Lopezgonzalez, J. T. Vazquez et al., "Multidisciplinary study of mud volcanoes and diapirs and their relationship to seepages and bottom currents in the Gulf of Cádiz continental slope (northeastern sector)," Marine Geology, vol. 378, pp. 196-212, 2016.

[42] X.-G. Chen, H.-Y. Zhang, X. Li, C.-T. A. Chen, T. F. Yang, and Y. Ye, "The chemical and isotopic compositions of gas discharge from shallow-water hydrothermal vents at Kueishantao, offshore northeast Taiwan," Geochemical Journal, vol. 50, no. 4, pp. 341-355, 2016.

[43] Y. Sano, N. Kinoshita, T. Kagoshima et al., "Origin of methane-rich natural gas at the West Pacific convergent plate boundary," Scientific Reports, vol. 7, no. 1, article 15646, 2017.

[44] D. F. Nash, "The geological development of the north Okinawa trough area from Neogene times to recent," Journal of the Japanese Association for Petroleum Technology, vol. 44, no. 5, pp. 341-351, 1979.

[45] W. S. Borowski, C. K. Paull, and W. Ussler, "Marine porewater sulfate profiles indicate in situ methane flux from underlying gas hydrate," Geology, vol. 24, no. 7, pp. 655658, 1996.

[46] J.-P. Blouet, P. Imbert, S. Ho, A. Wetzel, and A. Foubert, "What makes seep carbonates ignore self-sealing and grow vertically? The role of burrowing decapod crustaceans," Solid Earth Discussions, vol. 12, no. 10, pp. 1-44, 2020. 
[47] G. Bayon, S. Dupré, E. Ponzevera et al., "Formation of carbonate chimneys in the Mediterranean Sea linked to deep-water oxygen depletion," Nature Geoscience, vol. 6, no. 9, pp. 755760, 2013.

[48] D. Smrzka, D. Feng, T. Himmler et al., "Trace elements in methane-seep carbonates: potentials, limitations, and perspectives," Earth-Science Reviews, vol. 208, no. 103263, pp. 1-24, 2020.

[49] X. Zhang, Z. Sun, D. Fan et al., "Compositional characteristics and sources of DIC and DOC in seawater of the Okinawa Trough, East China Sea," Continental Shelf Research, vol. 174, pp. 108-117, 2019.

[50] X. Zhang, Z. Sun, L. Wang et al., "Distribution and discharge of dissolved methane in the middle Okinawa Trough, East China Sea," Frontiers in Earth Science, vol. 8, p. 333, 2020.

[51] S. Kawagucci, "Fluid geochemistry of high-temperature hydrothermal fields in the Okinawa Trough," in Subseafloor Biosphere Linked to Hydrothermal Systems, pp. 387-403, Springer, 2015.

[52] C. Waelbroeck, L. Labeyrie, E. Michel et al., "Sea-level and deep water temperature changes derived from benthic foraminifera isotopic records," Quaternary Science Reviews, vol. 21, no. 1, pp. 295-305, 2002.

[53] G. Li, P. Li, Y. Liu et al., "Sedimentary system response to the global sea level change in the East China Seas since the last glacial maximum," Earth-Science Reviews, vol. 139, pp. 390-405, 2014.

[54] M. J. Whiticar, "Carbon and hydrogen isotope systematics of bacterial formation and oxidation of methane," Chemical Geology, vol. 161, no. 1-3, pp. 291-314, 1999.

[55] J. W. Pohlman, M. Kaneko, V. B. Heuer, R. B. Coffin, and M. Whiticar, "Methane sources and production in the northern Cascadia margin gas hydrate system," Earth and Planetary Science Letters, vol. 287, no. 3-4, pp. 504-512, 2009. 